\title{
Przyznanie się oskarżonego do winy w rzymskim procesie karnym
}

Przyznanie się oskarżonego do winy stanowiło bez wątpienia w rzymskim procesie karnym - podobnie jak i dziś - najbardziej pożądany przez organy procesowe sposób zachowania się oskarżonego, który dostarczał upragnionego środka dowodowego, umożliwiającego zakończenie toczącego się postępowania. W niniejszym opracowaniu zostanie przedstawione w pierwszej kolejności to, jak pojmowano w rzymskim procesie karnym confessio ${ }^{1}$, a zwłaszcza jakie sposoby zachowania się oskarżonego traktowano jako przyznanie się do winy. Dalej zostanie omówiona kwestia sądowej oceny confessio w poszczególnych etapach historycznego rozwoju rzymskiego procesu karnego. W końcu, zostanie udzielona próba odpowiedzi na pytanie: czy sformułowana na gruncie rzymskiego procesu cywilnego zasada confessus pro iudicato est obowiązywała także w rzymskim postępowaniu karnym?

Jako przyznanie się do winy traktowano w rzymskim procesie karnym następujące sposoby zachowania się oskarżonego, które świadczyły o tym, że wina sprawcy była pewna (oczywista). Po pierwsze, winę sprawcy uznawano za pewną albo z powodu przyznania się do niej albo z powodu jawności czynu². Uznanie sprawcy za jawnie winnego mogło nastąpić w przypadku złapania go na

* Dr Andrzej Chmiel - Katedra Prawa Rzymskiego, Instytut Historii i Teorii Państwa i Prawa, Wydział Prawa i Administracji, Uniwersytet Marii Curie-Skłodowskiej w Lublinie; e-mail: andrzej. chmiel@poczta.umcs.lublin.pl.

${ }^{1}$ Ogólnie na temat confessio w rzymskim procesie karnym zob. zwłaszcza: G. Geib, De Confessionis Effectu in processu criminali romanorum, Turici 1837; T. Kipp, s.v. confessio, «RE» 4.1 (1900), szp. 870-871; J-M. David, La faute de l'abandon. Théories et pratiques judiciaires à Rome à la fin de la République, [w:] L’aveu. Antiquité et Moyen Âge. Actes de la table ronde de Rome (28-30 mars 1984), Roma 1986, s. 69-87; Y. Thomas, Confessus pro iudicato. L'aveu civil et l'aveu pénal à Rome, [w:] L'aveu. Antiquité et Moyen Âge. Actes de la table ronde de Rome (28-30 mars 1984), Roma 1986, s. 89-117.

${ }_{2}$ W. Kunkel, Prinzipien des römischen Strafverfahrens, [w:] Kleine Schriften. Zum römischen Strafverfahren und zur römischen Verfassungsgeschichte, Weimar 1974, s. 17. 
gorącym uczynku (fur manifestus; in flagranti). Taki los spotykał już w okresie królewskim sprawców perduellio, czyli zdrady stanu. Duumviri perduellionis przyłapując sprawcę na gorącym uczynku, wymierzali mu karę śmierci bez przeprowadzania dalszego postępowania rozpoznawczego ${ }^{3}$.

Według Ustawy XII Tablic, także złodziej przyłapany w dzień na gorącym uczynku był oddawany bez żadnego procesu przez magistraturę $\mathrm{w}$ ręce poszkodowanego ${ }^{4}$. $Z$ kolei ten sam sprawca przyłapany nocą in flagranti, mógł być według tego aktu prawnego nawet zabity5. Dopiero w prawie pretorskim, kiedy karę śmierci wobec sprawcy furtum manifestum zastąpiono karą grzywny, pojawiła się potrzeba przeprowadzenia procesu wobec złodzieja schwytanego na gorącym uczynku w celu wymierzenia mu kary ${ }^{6}$. Jednak zasada, że sprawcę fur manifestus należy uznać za jawnie winnego, obowiązywała dość długo w prawie rzymskim, o czym najlepiej świadczy poniższy przekaz Pomponiusza zawarty w Digestach Justyniana:
D. 12, 4, 15 (Pomponius libro vincesimo secundo ad Sabinum): Cum servus tuus in suspicionem furti Attio venisset, dedisti eum in quaestionem sub ea causa, ut, si id repertum in eo non esset, redderetur tibi: is eum tradidit praefecto vigilum quasi in facinore deprehensum: praefectus vigilum eum summo supplicio adfecit.

Według relacji jurysty, właściciel wydał swego niewolnika oskarżonego o kradzież poszkodowanemu w celu wyjaśnienia ciążącego na nim zarzutu, pod warunkiem, że jeśli nie zostanie on udowodniony, servus wróci do niego. Wbrew żądaniu właściciela, pokrzywdzony wydał jednak niewolnika prefektowi wigilów jako tego, który został złapany na gorącym uczynku?. Urzędnik jednak bez przeprowadzenia procesu nakazał go stracić.

3 B. Santalucia, Diritto e processo penale nell'antica Roma, Milano 1989, s. 21-22; W. Litewski, Rzymski proces karny, Kraków 2003, s. 107; por. A. Chmiel, Ustrój rzymskich organów jurysdykcyjnych w sprawach karnych, Studia Prawnoustrojowe 12 (2010), s. 50. Szerzej zob.: B. Santalucia, Osservazioni sui duuviri perduellionis e sul procedimento duumvirale, [w:] Du châtiment dans la cite. Supplices corporals et peine de mort dans le monde antique. Table ronde organisée par l'École française de Rome avec le concours du Centre national de la recherché scientifique (Rome 9-11 novembre 1982), Rome 1984, s. 439-452.

${ }^{4}$ (Lex duodecim tabularum) Tab. VIII, 14: Ex ceteris - manifestis furibus liberos verberari addicique iusserunt (Xviri) ei, cui furtum factum esset, si modo id luci fecissent neque se telo defendissent.

${ }^{5}$ (Lex duodecim tabularum) Tab. VIII, 12: Si nox furtum faxsit, si im occisit, iure caesus esto; zob. B. Santalucia, Il diritto penale e la codificazione decemvirale, [w:] Lineamenti di storia del diritto romano, red. M. Talamanca, Milano 1989, s. 131; por. E. Loska, Zagadnienie obrony koniecznej w rzymskim prawie karnym, Warszawa 2011, s. 23 i n..

${ }^{6}$ W. Kunkel, Prinzipien ..., s. 18. Por. L. Gagliardi, 'Iure caesus esto', Labeo 45 (1999), s. 430.

7 A. Wacke, Audiatur et altera pars zum rechtlichen gehoer im roemischen zivil- und strafprozess, [w:] Ars boni et aequi. Festsschrift fuer W. Waldstein zum 65., Stuttgart 1993, s. 387. O tym, kiedy kradzież była traktowana jako furtum manifestum - zob. D. 47, 2, 7, 1-3. 
Oczywistość przestępstwa, która wynikała z faktu ujęcia sprawcy w trakcie popełnienia czynu zabronionego, była traktowana jako przyznanie się do winy i stanowiła podstawę do wszczęcia egzekucji ${ }^{8}$. Dotyczyło to tych czynów, które były karane śmiercią lub deportacją ${ }^{9}$. Manifestus był traktowany tak samo jak confessus ${ }^{10}$. Właśnie obowiązywaniem tej zasady w prawie rzymskim Marek Porcjusz Katon usprawiedliwił swój głos za egzekucją uczestników spisku Katyliny:

Sall. Catil. 52, 36: „...de confessis, sicuti de manufestis rerum capitalium, more maiorum supplicium sumundum."

Confessio upraszczało zdecydowanie postępowanie sądowe. Sprawca, który przyznał się do winy lub też został ujęty in flagranti nie miał możliwości wniesienia provocatio ad populum ${ }^{11}$. Brak możliwości w takiej sytuacji odwołania się, można uzasadnić najprawdopodobniej w tym, iż w procesie karnym przynajmniej początkowo obowiązywał, wyrażony na gruncie prawa prywatnego zakaz venire contra factum proprium ${ }^{12}$ czyli zakaz zaprzeczania dokonanej przez siebie czynności ${ }^{13}$. Takie rozwiązanie było naturalną konsekwencją tego, iż przyznającego się do winy (confessus) traktowano jak zasądzonego (iudicatus). Jak widać, sformułowana na gruncie procesu cywilnego jeszcze w Ustawie XII Tablic $^{14}$, a następnie zredagowana przez Paulusa zasada: confessus pro iudicato est ${ }^{15}$, zamieszczona przez kompilatorów w tytule De confessis księgi XLII Digestów Justyniana ${ }^{16}$, obowiązywała - przynajmniej początkowo - także na gruncie procesu karnego ${ }^{17}$.

Przyznanie się oskarżonego do winy traktowano jako podstawę do skazania także w procesach przed urzędnikami magistraturalnymi. Taki przypadek miał

${ }^{8}$ W. Litewski, Rzymski ..., s. 107.

9 D. 48, 21, 3, 1; 3; zob. T. Mommsen, Römisches Strafrecht, Leipzig 1899 (nachdruck Graz 1955), s. 438; W. Litewski, Rzymski ..., s. 91.

${ }_{10}$ Zob. też - Seneca Maior, Contro. 8, 1: Confessio conscientiae vox est, (...); Quintilian, Declam. 314: Magistratus tamquam de confesso supplicium sumpsit.

${ }_{11}$ Tak - W. Litewski, Rzymski...., s. 31.

12 Zob. D. 1, 7, 25 pr..

${ }_{13}$ Por. uwagi na gruncie prawa prywatnego - D. Nörr, Causa mortis, München 1986, s. 156.

${ }^{14}$ Por. (Lex duodecim tabularum) Tab. III, 1: Aeris confessi rebusque iure iudicatis XXX dies iusti sunto.

${ }^{15}$ Szerzej na temat tej zasady w rzymskim prawie prywatnym - zob. Y. Thomas, op. cit., s. 89-97; W. Litewski, Confessio in iure e sententia, Labeo 22/2 (1976), s. 252-267; N. Scapini, La confessione nel diritto romano. I: Diritto classico, Torino 1973; idem, La confessione nel diritto romano. II: Diritto giustinianeo, Milano 1983.

${ }^{16}$ D. 42, 2, 1 (Paulus libro quinquagensimo sexto ad edictum): Confessus pro iudicato est, qui quodammodo sua sententia damnatur; zob. też: D. 42, 1, 51; 42, 2, 3; C. 7, 59, 1.

${ }_{17}$ Zob. W. Kunkel, Prinzipien ...., s. 19; nieco odmiennie w tej kwestii - por Y. Thomas, op. cit., s. 97 przyp. 26. 
miejsce jeszcze chociażby podczas procesu Kampańczyków oskarżonych o pożar Rzymu w 211 r. p.n.e. ${ }^{18}$, czy też w sprawie wyznawców Bachusa z 186 r. p.n.e. ${ }^{19}$. Także w procesach karnych przed stałymi sądami przysięgłych przyznanie się oskarżonego do winy mogło być traktowane jako podstawa do skazania. Z przytoczonego poniżej przekazu Paulusa wynika, iż taka możliwość istniała w procesach de vi toczących się na podstawie lex Iulia de vi publica ${ }^{20}$ :

\begin{abstract}
PS. 5, 26, 2: Hac lege excipiuntur, qui artem ludicram faciunt, iudicati etiam et confessi et qui ideo in carcerem duci iubentur, quod ius dicenti non obtemperaverint quidve contra disciplinam publicam fecerint: tribuni etiam militum et praefecti classium alarumve, ut sine aliquo impedimento legis luliae per eos militare delictum coerceri possit.
\end{abstract}

Także wypowiedź Cycerona, przywołana w mowie pro Ligario w obronie swojego klienta, potwierdza, iż confessio mogło stanowić podstawę do wydania skazującego wyroku:

Cic. pro Ligat. I, 2: Habes igitur, Tubero, quod est accusatori maxime optandum, confitentem reum ${ }^{21}$.

Według przekazu Arpinaty, przyznanie się oskarżonego do winy było uznawane w jego czasach, za najbardziej pożądany przez oskarżyciela dowód w sprawie.

Confessio stanowiło wystarczającą podstawę do wydania skazującego wyroku także przed sądem cesarskim, przynajmniej w początkowym okresie pryncypatu. Co ciekawe, w procesach o parricidium karę worka można było orzec wobec oskarżonego wyłącznie, jeżeli przyznał się do winy lub został ujęty na gorącym uczynku przestępstwa ${ }^{22}$. O jednym takim przypadku, który odbył się

${ }^{18}$ Liv. Ab urbe condita, XXVI, 27.

${ }^{19} \mathrm{~W}$ przypadku tych ostatnich, jak wiadomo z przekazu Liwiusza (Liv. Ab urbe condita, XXXIX, 17): „Postarano się zatem, aby tych ludzi możliwie szybko ująć. Przyprowadzono ich przed konsulów. Tu przyznali się do winy nie stwarzając żadnej przeszkody w wydaniu wyroku." - tłum. cyt. za: Tytus Liwiusz, Dzieje Rzymu od założenia miasta, ks. XXXV-XL, przeł. i oprac. M. Brożek, Wrocław-Warszawa-Kraków-Gdańsk-Łódź 1981, s. 280. Szerzej na temat procesu wyznawców Bachusa- M. Jońca, Głośne rzymskie procesy karne, Wrocław 2009, s. 87 i n..

${ }^{20}$ Zob. W. Kunkel, Prinzipien..., s. 19; W. Litewski, Rzymski ..., s. 107.

${ }^{21}$ Tłum: „Masz tedy, Tuberonie, czego sobie oskarżyciel, najwięcej życzyć powinien, przyznającego się do winy obżałowanego,...”- cyt. za: Mowy Marka Tulliusza Cycerona, przeł. przez E. Rykaczewskiego, t. III, Paryż 1870, s. 303.

${ }_{22}$ Zob. W. Rein, Das Criminalrecht der Römer von Romulus bis auf Justynian, Leipzig 1844. s. 460; por. T. Mommsen, op. cit., s. 437; zob. A. Dębiński, Poena cullei w rzymskim prawie karnym, Prawo Kanoniczne 37 nr 3-4 (1994), s. 142. 
przed sądem cesarskim, któremu przewodniczył August, wspomina chociażby Swetoniusz w swoim dziele De vita Caesarum:

Suet. Aug, 33: Dixit autem ius non diligentia modo summa sed et lenitate, siquidem manifesti parricidii reum, ne culleo insueretur, quod non nisi confessi adficiuntur hac poena, ita fertur interrogasse: "Certe patrem tuum non occidisti?" 23 .

Z przywołanego przekazu wynika, iż przyznanie się do winy mogło uzasadniać orzeczenie kary głównej. Pomimo tego, iż w okresie pryncypatu przedstawiciele honestiores byli co do zasady karani łagodniej niż osoby należące do kategorii humiliores, to jednak nawet w przypadku parricidium, przyznanie się oskarżonego oznaczało raczej nikłą możliwość skazania na łagodniejszą karę ${ }^{24}$.

Jako przyznanie się do winy traktowano w rzymskim procesie karnym również sytuację w której osoba oskarżona o przestępstwo zagrożone karą śmierci bądź wygnania popełniła samobójstwo ${ }^{25}$. W tym przypadku, jedynie nieusprawiedliwione samobójstwo oskarżonego, a wiec takie które miało na celu jedynie uchronić jego spadkobierców przed egzekucją, mogło być potraktowane jako przyznanie się do winy ${ }^{26}$.

Poza samobójstwem, także ucieczka oskarżonego $\mathrm{z}$ aresztu była traktowana jako przyznanie się do winy. Nieobecność oskarżonego czyniła w takim przypadku zbędnym przeprowadzenie postępowania sądowego ${ }^{27}$.

Jako przyznanie się do winy uważano również według konstytucji wydanej przez cesarzy Septymiusza Sewera oraz Karakallę, próbę przekupienia oskarżyciela przez oskarżonego ${ }^{28}$. W tym przypadku, zachowanie oskarżonego

${ }^{23}$ Tłum: „Wyroki ferował nie tylko z najwyższą starannością, lecz także w wyjątkową łagodnością. Oto na przykład w obawie aby oskarżonego o jawne ojcobójstwo nie skazano na karę zaszycia w wór, wiedząc że karę zasądzano tylko w wypadku przyznania się do winy, tak podobno go zapytał: „Oczywiście ojca nie zabiłeś?” - cyt. za: Gajus Swetoniusz Trankwillus, Żywoty Cezarów, przeł. J. Niemirska-Pliszczyńska, wyd. 5, Wrocław-Warszawa-Kraków-Gdańsk 1972, s. 130.

${ }^{24}$ Por. M. Jońca, Parricidium w prawie rzymskim, Lublin 2008, s. 248. Szerzej na temat dychotomii pomiędzy honestiores i humiliores w rzymskim prawie karnym - zob. R. Rilinger, Honestiores - Humiliores: zu einer sozialen Dichotomie im Strafrecht der römischen Kaiserzeit, München 1988.

${ }_{25}$ D. 24, 1, 32, 7; 48, 21, 3 pr.; 49, 14, 45, 2; C. 3, 26; zob. T. Mommsen, op. cit., s. 438.

${ }^{26}$ A. Wacke, Der Selbsmord im römischen Recht und der Rechtsentwicklung, ZSS 97 (1980), s. 61. Ostatnio na temat samobójstwa oskarżonego - zob. M. Frantzen, Mors voluntaria in reatu: Die Selbsttötung im klassischen römischen Recht, Gottingen 2012; A. Manni, Mors omnia solvit. La morte del reus nel processo criminale romano, Napoli 2013; V. Marotta, Morte rei iudicium solvitur, INDEX 43 (2015), s. 456-464; zob. też: A. Chmiel, Zasada crimen extinguitur mortalitate a samobójstwo oskarżonego w rzymskim procesie karnym, [w:] Justynian i prawo rzymskie. Refleksje w 1450. Rocznice śmierci cesarza, pod red. K. Szczygielskiego, Białystok 2015, s. 97-112.

${ }^{27}$ W. Kunkel, Prinzipien...., s. 19.

${ }^{28}$ D. $48,21,2$ pr.. 
pojmowano jako przykład pewnego potępienia samego siebie, który był równoznaczny z confessio ${ }^{29}$.

Jako przyznanie się do winy traktowano również rezygnację oskarżonego $\mathrm{z}$ obrony podczas procesu - defensionem reliquit ${ }^{30}$. Taka rezygnacja niekiedy mogła przybrać postać milczenia. To ostatnie, traktowano jako rezygnację oskarżonego zarówno z możliwości wyjaśnienia swojej niewinności, jak również $\mathrm{z}$ domagania się od oskarżyciela udowodnienia winy ${ }^{31}$. Najlepiej obrazuje to przykład uczestników spisku Katyliny ${ }^{32}$. Takie przyznanie się do winy czyniło zbędnym przeprowadzanie dalszego postępowania sądowego ${ }^{33}$.

Przywołane przykłady potwierdzają, iż rzymskim procesem karnym - podobnie jak i cywilnym - przynajmniej w początkowym okresie, rządziła wyrażona już w Ustawie XII Tablic (Tab. III, 1), zasada stawiająca confessus, czyli przyznającego się do winy na równi z iudicatus czyli zasądzonym ${ }^{34}$.

W tym miejscu należałoby odpowiedzieć na pytanie: dlaczego przyznaniu się oskarżonego do winy w okresie republiki, a także w początkowym okresie pryncypatu, przyznawano nieograniczoną wiarygodność i stanowiło ono podstawę do skazania na najsurowszą z możliwych kar, czyli karę śmierci?

Obecnie, w polskim prawie karnym przyznanie się oskarżonego do winy i podjęcie przez niego współpracy z organami ścigania, stanowią okoliczności łagodzące ${ }^{35}$. Co ciekawe, starożytni Kwiryci jednak bardzo surowo traktowali sprawców przyznających się do popełnionych przez siebie czynów. Zdaniem A. W. Zumpta, wynikało to z postawy samych Rzymian. Według tego badacza, starożytni Rzymianie byli świadomi ludzkiej omylności sądzących. Ci ostatni bardzo często byli podatni na wpływy zgromadzonej podczas rozprawy

29 Por. W. Kunkel, Prinzipien...., s. 19.

${ }^{30}$ Ibidem, s. 19; por. J. Ermann, Strafprozeß, öffentliches Interesse und private Strafverfolgung, Köln-Weimar-Wien 2000, s. 65.

31 W. Kunkel, Prinzipien...., 19; por. J. Ermann, op. cit., s. 65.

32 Zob. A. Chmiel, Proces katylinarczyków jako przykład rzymskiego "procesu politycznego”, [w:] Prawo karne i polityka w państwie rzymskim, red. K. Amielańczyk, A. Dębiński, D. Słapek, Lublin 2015, s. 59 i n.

${ }^{33}$ Co ciekawe, zasada, że wina oskarżonego, który przyznał się do niej nie musi być następnie udowodniona sądownie, obowiązuje dziś w angielskim postępowaniu karnym. Przyznanie się oskarżonego do winy (plea of quilty) stanowi kluczową instytucję procesową, która umożliwia rozpoznawanie sprawy bez przeprowadzania rozprawy sądowej. Pozwala to na skrócenie postępowania i przejście od razu do wymierzenia oskarżonemu kary - szerzej na temat instytucji plea of guilty - zob. A. Sanders, R. Young, M. Burton, Criminal Justice, wyd. IV, Oxford University Press, New York 2010, s. 460 i n.; zob. też K. Girdwoyń, Ogólna charakterystyka procesu karnego w Anglii $i$ Walii, [w:] System prawa karnego procesowego, t. II. Proces karny. Rozwiązania modelowe w ujęciu prawnoporównawczym, red. P. Kruszyński, Warszawa 2014, s. 687.

34 Por. W. Kunkel, Prinzipien ..., s. 19.

35 Por. A. Marek, Prawo karne, Warszawa 2006, s. 343. 
publiczności ${ }^{36}$. Z tego powodu zdaniem A.W. Zumpta, w postępowaniu sądowym należało wymierzyć oskarżonemu z reguły szczególną, ale łagodniejszą karę, którą stała się - stosowana już w okresie republiki w procesie komicjalnym kara wygnania ${ }^{37}$. W sytuacji, kiedy jednak sprawca przyznał się do winy, można było przyjąć na tej podstawie, że w rzeczywistości jest on winny i zasługuje na właściwą, czyli ciężką karę. Takie podejście w pewnym zakresie uzasadniało stawianie sprawcy przyznającego się do winy, na równi z manifestus, czyli ujętym na gorącym uczynku.

Nie ulega wątpliwości, iż wyraz omylności wobec sądzących, Rzymianie dawali w przyjętym sposobie głosowania nad wyrokiem, zwłaszcza w procesach przed stałymi sądami przysięgłych. $\mathrm{W}$ postępowaniu przed quaestiones perpetuae sędziowie mogli uznać sprawcę za winnego („C” - condemno) lub nie („A" - absolvo), albo też wstrzymać się od głosu („NL” - „non liquet”)

W tym miejscu powstaje pytanie: skąd wziął się u Rzymian taki sposób karania sprawców przestępstw? Zdaniem A. W. Zumpta, wynikał on z tego, iż w tym okresie nie wykształciły się jeszcze w pełni zasady sądowego wymiaru kary, a także, co było ściśle z tym związane, reguły dotyczące oceny nastawienia psychicznego sprawcy do czynu ${ }^{39}$. Rzymskie prawo karne okresu republiki oceniało sprawcę czynu tylko z punktu widzenia jego skutków ${ }^{40}$. Nie brało zaś pod uwagę motywów jego działania. Podstawą pociągnięcia sprawcy do odpowiedzialności karnej był jedynie obiektywny fakt popełnienia określonego czynu zagrożonego karą.

To, że jeszcze w okresie republiki rzymskie prawo karne oceniało działanie sprawcy czynu tylko z punktu widzenia jego skutków, najlepiej ilustruje sposób, w jaki traktowano przedmiot samego procesu karnego. Celem postępowania karnego było wyłącznie ustalenie, czy oskarżony jest winny tzn. czy popełnił

36 A.W. Zumpt, Römisches Criminalrecht, t. I.1, Berlin 1865, s. 181, 376. Na temat znaczenia opinii publicznej w rzymskim procesie karnym - zob. K. Amielańczyk, Znaczenie “opinii publicznej” dla przebiegu rzymskiego procesu karnego. Uwagi na marginesie mów obrończych Cycerona w sprawach o zabójstwa, [w:] Społeczeństwo a władza. Ustrój, prawo, idee, pod. red. J. Przygodzkiego i M.J. Ptaka, Kolonia Limited 2010, s. 145-160.

37 Na temat kary wygnania w rzymskim prawie karnym - M. Jońca, Exilium jako przejaw humanitas w rzymskim prawie karnym okresu republiki, [w:] Humanitas grecka i rzymska, pod red. R. Popowskiego, Lublin 2005, s. 191 i n; idem,; The Scope of exilium voluntarium in the Roman Republic, [w:] La repressione criminale nella Roma repubblicana fra norma e persuasione, (a cura di B. Santalucia), Pavia 2009, s. 77-91. Zob. też: G.P. Kelly, A History of Exile in the Roman Republic, Cambridge 2006 oraz recenzję tej pracy - M. Jońca, Exilium voluntarium, czyli luksus dla wybranych, CPH, t. LX, z. 2 (2008) s. 363-369.

38 Zob. W. Kunkel, Quaestio, [w:] Kleine Schriften. Zum römischen Strafverfahren und zur römischen Verfassungsgeschichte, Weimar 1974, s. 86.

39 A.W. Zumpt, op. cit., s. 376.

${ }^{40}$ Por. też: C. Gioffredi, L'elemento intenzionale nel diritto penale romano, [w:] Studi in onore di G. Grosso III, Torino 1970, s. 37. 
zarzucany mu czyn, czy też nie ${ }^{41}$. Najlepiej potwierdza to słowna formuła za pomocą której ogłaszano treść wyroku w procesie przed quaestiones perpetuae. Przewodniczący quaestio stwierdzał: fecisse videtur czyli, on to zrobił lub non fecisse - on tego nie zrobił ${ }^{42}$. W dalszej kolejności następowało już tylko wymierzenie kary, która była $\mathrm{z}$ góry określona w ustawie. W takim warunkach, złagodzenie kary ze względu na motywy działania sprawcy było nie do przyjęcia. Jeżeli zatem sprawca przyznał się, to wówczas należało uznać, że czyn został popełniony przez niego. To z kolei rodziło przesłanki pozwalające na nałożenie kary w najwyższym jej wymiarze.

W tym miejscu można zadać pytanie: dlaczego system quaestiones perpetuae został skonstruowany w sposób, który nie pozwalał sędziom na jakąkolwiek modyfikację określonej w ustawie kary? Brak wspomnianych zasad sądowego jej wymiaru oraz reguł dotyczących oceny nastawienia psychicznego sprawcy do czynu wymusił przyjęcie takiego a nie innego sposobu funkcjonowania sądów przysięgłych. Sędziowie quaestiones perpetuae mieli jedynie za zadanie, albo uznać, że sprawca popełnił zarzucany mu czyn i skazać go na określoną w ustawie karę, lub uwolnić go. Istniała jeszcze trzecia możliwość. Sędziowie mający wątpliwości co winy sprawcy, mogli wstrzymać się od głosu. System quaestiones nie dopuszczał jednak żadnej możliwości wpłynięcia na zakres sądowego wymiaru kary. Prawo sędziów do powstrzymania się od głosowania i uznanie sprawy za niedostatecznie jasną („non liquet”) stanowiło jednak duży postęp w sposobie procedowania na kwestią winy sprawcy, w stosunku chociażby do procesu komicjalnego ${ }^{43}$.

Zmiana w sposobie traktowania przyznania się oskarżonego do winy nastąpiła bez wątpienia już na przełomie II i III w. n.e. ${ }^{44}$. Taki wniosek nasuwa poniższy przekaz Ulpiana:

D. 48, 18, 1, 17 (Ulpianus libro octavo de officio proconsulis): Divus Severus rescripsit confessiones reorum pro exploratis facinoribus haberi non oportere, si nulla probatio religionem cognoscentis instruat.

Jurysta przywołał w swej relacji treść reskryptu wydanego przez cesarza Septymiusza Sewera. Według cesarskiego rozporządzenia, nie powinno się traktować przyznania się oskarżonych do winy jako dowodu służącego do wykrycia

\footnotetext{
${ }^{41}$ Por. A. Wacke, Audiatur ..., s. 387

${ }^{42}$ Zob. W. Kunkel, Prinzipien ..., s. 16; idem, Quaestio ..., s. 87.

${ }^{43} \mathrm{~W}$ procesie przed iudicium populum pełniący rolę sędziego lud mógł jedynie albo uznać oskarżonego za winnego („C” - condemno) lub niewinnego („A” - absolvo) i musiał oprzeć swoją decyzję tylko na tych dowodach jakie dostarczyły mu strony - por. N. Scapini, Diritto e procedura penale nell'esperienza giuridica romana, Parma 1992, s. 129.

${ }^{44}$ Por. W. Kunkel, Prinzipien ..., s. 19.
} 
przestępstwa, jeżeli nie ma żadnych innych dowodów, którymi mógłby kierować się sędzia rozpoznający sprawę. Z przywołanego przekazu wynika, iż w okresie pryncypatu w rzymskim postępowaniu karnym przestała obowiązywać zasada confessus pro iudicato est.

To, iż przyznanie się oskarżonego do winy nie było w tym okresie traktowane jako wyłączna podstawa do skazania, potwierdzają jeszcze inne teksty źródłowe:

D. 48, 18, 1, 27 (Ulpianus libro octavo de officio proconsulis): Si quis ultro de maleficio fateatur, non semper ei fides habenda est: nonnumquam enim aut metu aut qua alia de causa in se confitentur. Et extat epistula divorum fratrum ad Voconium Saxam, qua continetur liberandum eum, qui in se fuerat confessus, cuius post damnationem de innocentia constitisset. (... $)^{45}$

Z powyższego przekazu Ulpiana, zawartego w tytule De quaestionibus Digestów Justyniana wynika, iż dobrowolnemu przyznaniu się do winy nie zawsze należało dawać wiarę. Kwestia wiarygodności confessio oskarżonego poruszona została przez tego jurystę jeszcze w innym paragrafie zamieszczonym w przywołanym powyżej tytule kompilacji justyniańskiej:

\section{48, 18, 1, 23 (Ulpianus libro octavo de officio proconsulis): Quaestioni fidem non semper nec tamen numquam habendam constitutionibus declaratur: etenim res est fragilis et pericu- losa et quae veritatem fallat. Nam plerique patientia sive duritia tormentorum ita tormenta contemnunt, ut exprimi eis veritas nullo modo possit: alii tanta sunt impatientia, ut quodvis mentiri quam pati tormenta velint: ita fit, ut etiam vario modo fateantur, ut non tantum se verum etiam alios criminentur ${ }^{46}$}

Z przywołanych przekazów wynika, iż przyznanie się oskarżonego do winy w okresie pryncypatu, a przynajmniej na przełomie II i III wieku n.e., nie stanowiło w świetle cesarskim konstytucji wyłącznej podstawy do wydania skazującego wyroku. Samo confessio było traktowane jak zwykły dowód, a mianowicie jako

45 Tłum: „Jeśli ktoś dobrowolnie przyznaje się < do popełnienia> przestępstwa, nie zawsze należy mu wierzyć. Niekiedy bowiem <oskarżeni> przyznają się z powodu strachu lub innej przyczyny. Istnieje list boskich braci do Vaconiusa Saxy, zawierający <zasadę>, zgodnie z którą należy uwolnić tego, kto przyznał się <do popełnienia czynu>, a po skazaniu okazało się, że był niewinny. (...) - cyt. za: Digesta Iustiniani. Digesta Justyniańskie. Tekst i przekład, VII, 2, ks. 48-50, pod red. T. Palmirskiego, Kraków 2017, s. 117.

46 Tłum: „W rozporządzeniach <cesarskich> zostało wskazane, że nie zawsze należy dawać wiary <zeznaniom uzyskanym > na torturach. Sprawa jest bowiem niepewna i ryzykowana oraz może $<$ ukryć $>$ prawdę. Liczni bowiem ze względu na zahartowanie oraz wytrzymałość na tortury tak bardzo je lekceważą, że prawda w żaden sposób nie może od nich być wydobyta. Inni <natomiast > są tak niewytrzymali, że wolą skłamać cokolwiek, niż znosić ból. I tak się zdarza, że na różne sposoby przyznają się do winy, ale nie tylko sami, lecz również innych sami obwiniają.” - cyt. za: Digesta Iustiniani..., s. 117. 
wyjaśnienia, które należało jednak zweryfikować zwłaszcza w oparciu o inne probationes.

W tym miejscu należy zadać pytanie: dlaczego akurat w tym okresie nastąpiła w rzymskim procesie karnym zmiana w zakresie sposobu przeprowadzania sądowej oceny przyznania się oskarżonego do winy? W pryncypacie, a zwłaszcza w okresie panowania cesarzy z dynastii Antoninów, a następnie Sewerów, widać pewne zainteresowanie ustawodawcy kwestią szeroko pojętego zawinienia sprawcy przestępstwa. Szczególną uwagę temu zagadnieniu poświęcił w swych reskryptach cesarz Hadrian ${ }^{47}$. Nie ulega wątpliwości, iż jego działalność w dużej mierze przyczyniła się do wzrostu zainteresowania jurysprudencji tą problematyką. To właśnie on za sprawą swojej reskryptowej działalności na gruncie sullańskiej lex Cornelia de sicariis et veneficiis doprowadził do karalności nieumyślnego zabójstwa, jak również usiłowania zabójstwa ${ }^{48}$. W okresie archaicznego rozwoju rzymskiego prawa karnego wyłączną podstawą uznania danego zachowania za przestępstwo był jedynie czyn sprawcy powodujący przestępczy skutek w postaci szkody ${ }^{49}$. Co prawda już w ustawodawstwie króla Pompiliusza Numy wina sprawcy została potraktowana jako przesłanka umożliwiająca pociągniecie sprawcy do odpowiedzialności karnej ${ }^{50}$. Jednak dopiero za sprawą reskryptowej działalności cesarzy oraz interpretacyjnej aktywności jurystów, stworzono w okresie pryncypatu podstawy nauki o stronie podmiotowej przestępstwa ${ }^{51}$.

Aby uznać wyjaśnienia oskarżonego jako zawierające przyznanie się do winy powinny one potwierdzać zarówno stronę przedmiotową, jak podmiotową przestępstwa $^{52}$. Już starożytni Rzymianie bardzo dobrze zdawali sobie $\mathrm{z}$ tego sprawę, iż samo przyznanie się do winy nie było wystarczające do skazania i wymierzenia oskarżonemu kary. Samo confessio mogło przecież potwierdzać jedynie to, iż sprawca brał udział w popełnionym przestępstwie. Jednak, aby pociągnąć go do odpowiedzialności karnej, należało ustalić stopień jego winy. Z kolei, aby móc określić ten ostatni, należało zbadać zwłaszcza motywy działania sprawcy. Co ciekawe, już starożytni Rzymianie zwracali na to uwagę, zwłaszcza w przypadku tych czynów zabronionych, które mogły zostać popełnione przez kilka osób. Najlepszy tego przykład stanowiło przestępstwo nieudzielenia przez

47 Szerzej zob. K. Amielańczyk, Rzymskie prawo karne w reskryptach cesarza Hadriana, Lublin 2006, s. 64 i n..

${ }^{48}$ K. Amielańczyk, Crimina legitima w rzymskim prawie publicznym, Lublin 2013, s. 125; szerzej - zob. idem, Lex Cornelia de sicariis et venefisis. Ustawa Korneliusza Sulli przeciwko nożownikom i trucicielom 81 r.p.n.e., Lublin 2011, s. 136 i n..

${ }^{49}$ Idem, Crimina legitima ..., s. 126; zob. C. Giofredi, op. cit., s. 37 i n..

${ }^{50}$ Zob. Lex Numae, 12: Si quis hominem liberum dolo sciens mortui duit; parricidas esto; zob. K. Amielańczyk, Crimina legitima ..., s. 126 i n..

${ }^{51}$ K. Amielańczyk, Crimina legitima ..., s. 126

${ }^{52}$ Por. R. Kmiecik (red.), Prawo dowodowe. Zarys wykładu, Warszawa 2008, s. 148. 
niewolnika pomocy swemu panu podczas zamachu na jego życie, spenalizowane w s.c. Silanianum ${ }^{53}$. O tym, iż w czasie prowadzonego w takiej sprawie śledztwa, należało zwrócić uwagę przede wszystkim na motywy działania sprawców, świadczy poniższy przekaz Modestinusa:

D. 29, 5, 17 (Modestinus libro octavo regularum): Prius de se familia torquenda est et, si confiteatur, tunc interrogetur, quo mandante flagitium admissum sit.

Według jego relacji, niewolnicy powinni zostać poddani torturom w związku z ich własnymi czynami i jeżeli się przyznają, należy ich przesłuchać pod względem tego, kto zlecił popełnienie zbrodni.

Do tego samego, co wyrażony powyżej przez Modestinusa, sposobu postępowania w czasie quaestio nawiązał również Paulus, w księdze XLVI swego dzieła Ad edictum:

D. 29, 5, 6 pr. (Paulus libro quadragensimo sexto ad edictum): Etsi percussor certus sit, tamen habenda quaestio est, ut caedis mandator inveniatur: utique autem ipse maxime quaestioni dabitur, quamvis et ceteri puniantur.

O tym, jak duże znaczenie przywiązywali Rzymianie podczas sądowej oceny dowodów zarówno do motywów działania sprawcy, jak i całej sfery, psychologicznej oceny osobowych środków dowodowych, świadczą niektóre opinie sformułowane przez jurystów rzymskich. I tak, według przywołanego już przekazu Ulpiana (D.48, 18, 1, 27) jako przyczynę fałszywego przyznania się do winy traktowano np. strach oskarżonego być może grożącą mu karą lub cierpieniem związanym z torturami, albo też obawę przed tym, by nie został wydany przez inne osoby w czasie przesłuchania ${ }^{54}$.

${ }^{53}$ Por. E. Loska, Obowiązek niewolników obrony swojego właściciela, Zeszyty Prawnicze UKSW 4.1 (2004), s. 45-56; K. Amielańczyk, Głos cesarza Hadriana w sprawie s.c. Silanianum, [w:] Zeszyty Prawnicze UKSW 6.1 (2006), s. 9-25. Ostatnio w polskiej romanistyce na temat tej uchwały: A. Chmiel, Ochrona bezpieczeństwa właścicieli niewolników w świetle S.C. Silanianum, [w:] Ochrona bezpieczeństwa i porządku publicznego w prawie rzymskim, pod. red. K. Amielańczyka, A. Dębińskiego, D. Słapka, Lublin 2010, s. 53-64; idem, Przykład zastosowania s.c. Silanianum, czyli o tym, dlaczego rzymska iustitia stawała się niekiedy okrutna, [w:] Przemoc w świecie starożytnym. Źródła, struktury, interpretacje, red. D. Słapek, I. Łuć, Lublin 2017, s. 299-310.

${ }^{54}$ Zob. D. 48, 18, 1, 26 (Ulpianus libro octavo de officio proconsulis): Cum quis latrones tradidit, quibusdam rescriptis continetur non debere fidem haberi eis in eos, qui eos tradiderunt: quibusdam vero, quae sunt pleniora, hoc cavetur, ut neque destricte non habeatur, ut in ceterorum persona solet, sed causa cognita aestimetur, habenda fides sit nec ne. Plerique enim, dum metuunt, ne forte adpprehensi eos nominent, prodere eos solent, scilicet impunitatem sibi captantes, quia non facile eis indicantibus proditores suos creditur. Sed neque passim impunitas eis per huiusmodi proditiones concedenda est, neque transmittenda allegatio dicentium idcirco se oneratos, quod eos ipsi tradidissent: neque enim invalidum argumentum haberi debet mendacii sive calumniae in se instructae. 
Warto zwrócić uwagę, iż istotna zmiana w sposobie traktowania przyznania się do winy nastąpiła wówczas, kiedy upowszechniła się w rzymskim procesie karnym praktyka stosowania tortur. Te ostatnie, były uznawane nawet przez samych Rzymian jako wątpliwy i nie zawsze najlepszy sposób dochodzenia do prawdy, o czym mogą świadczyć wypowiedzi niektórych jurystów, chociażby Ulpiana, zawarte w tytule De quaestionibus Digestów Justyniana ${ }^{55}$. Nie dziwi zatem treść przywołanej już konstytucji Septymiusza Sewera według której, samo przyznanie się do winy nie mogło stanowić wyłącznej podstawy skazującego wyroku. Także z relacji innych jurystów wynika, iż confessio przestało być traktowane - przynajmniej w okresie późnego pryncypatu - jako koronny dowód, który kończył natychmiast postępowanie karne:

D. 48, 3, 5 (Venuleius libro secundo de iudiciis publicis): Si confessus fuerit reus, donec de eo pronuntietur, in vincula publica coiciendus est.

Według przekazu Venuleiusa, oskarżonego, który przyznał się do winy należało umieścić w publicznym więzieniu do czasu, kiedy zapadnie wyrok w jego sprawie. Zatem, jeżeli później znalazłyby się jakieś dowody potwierdzające jego niewinność, powinien zostać zwolniony.

To, iż confessio oskarżonego także w okresie poklasycznym było oceniane swobodnie i nie było traktowane jako koronny dowód w procesie karnym, potwierdza treść konstytucji wydanej przez cesarza Konstantyna Wielkiego:

\begin{abstract}
C. 7, 65, 2 (Imperator Constantius): Observare curabis, ne quis homicidarum veneficorum maleficorum adulterorum itemque eorum, qui manifestam violentiam commiserunt, argumentis convictus, testibus superatus, voce etiam propria vitium scelusque confessus audiatur appellans. 1 . Sicut enim haec ita observari disposuimus, ita aequum est testibus productis, instrumentis prolatis aliisque argumentis praestitis, si sententia contra eum lata sit et ipse, qui condemnatus est aut minime voce sua confessus sit aut formidine tormentorum tentus contra se aliquid dixerit, provocandi licentiam ei non denegari. * CONSTANTIUS A. AD HIEROCLEM. ${ }^{*}<$ A 344 D. V ID. DEC. LEONTIO ET SALLUSTIO CONSS.>
\end{abstract}

${ }^{55}$ Ogólnie na temat tortur i wartości dowodowej uzyskanych przy ich udziale zeznań - zob. B. Sitek, "Quaestionem” intellegere debemus tormenta et corporis dolorem ad eruendam veritatem, [w:] Crimina et mores. Prawo karne i obyczaje w starożytnym Rzymie, pod red. M. Kuryłowicza, Lublin 2001, s. 161-168; K. Amielańczyk, Quaestio per tormenta. O wartości dowodowej zeznań uzyskanych za pomoca tortur w rzymskim procesie karnym okresu pryncypatu, [w:] O prawie i jego dziejach. Ksiegi dwie. Studia ofiarowane Profesorowi Adamowi Lityńskiemu w czterdziestopięciolecie pracy naukowej i siedemdziesięciolecie urodzin, Ks. I, Białystok-Katowice 2010, s. 51-62; A. Chmiel, Ochrona bezpieczeństwa właścicieli ..., s. 62 i n.. 
W myśl jej postanowień możliwe było wniesienie apelacji od wyroku opartego na przyznaniu się, które zostało złożone ze strachu przed torturami.

Oczywiście, jak zawsze zdarzały się pewne wyjątki. I tak, w przypadku określonych kategorii przestępstw przyznanie się do winy niekiedy stanowiło dopuszczalną podstawę do skazania oskarżonego. Tak było już w pryncypacie w przypadku procesów chrześcijan, gdzie sam fakt przyznania się do bycia chrześcijaninem był równoznaczny ze skazaniem ${ }^{56}$. W okresie poklasycznym podobnie postępowano wobec sprawców takich czynów jak np. dezercja z wojska ${ }^{57}$, czy też wobec osób dopuszczających się przestępstw religijnych, np. sacrilegium $^{58}$. W przypadku tego ostatniego czyli świętokradztwa, przyznanie się do winy wręcz upoważniało sąd do nałożenia jeszcze cięższej kary ${ }^{59}$. Przywołane sytuacje były jednak szczególne i dotyczyły czynów wymierzonych przeciwko szeroko pojętemu majestatowi państwa ${ }^{60}$.

${ }^{56} \mathrm{Na}$ temat procesów chrześcijan zob.: M. Jońca, $<$ In > iis qui ad me tamquam christiani deferebantur, hunc sum secutus modum. Środki dowodowe zastosowane w procesie chrześcijan pontyjskich w relacji Pliniusza Młodszego (Ep. 10, 96), Zeszyty Prawnicze UKSW 5.2 (2005), s. 99-115; 103; M.H. Dyjakowska, Procesy chrześcijan w świetle korespondencji Pliniusza Młodszego, [w:] Cuius regio, eius religio, Lublin 2006, s. 25-40.

${ }_{57}$ C.Th. 7, 18, 11 (Idem aa. et Theodosius a. Hadriano praefecto praetorio): pr. Si qui desertores oberrare in provinciis fuerint comprehensi, eos et comprehendi protinus volumus et ad iudicem deduci, ut auditi, cum de crimine desertionis suae confessi fuerint, carceris custodiae deputentur: de quorum nominibus ad tuam sublimitatem subditis confessionibus referatur, ut instructi magistri militum, quid de his fieri oporteat, pro sui auctoritate constituant. Sin vero inventi resistendum atque armis obtinendum putaverint, tamquam rebelles in ipsis temeritatis suae conatibus opprimantur: 1. Ita tamen, ut provinciarum iudices sollicita cautione disquirant, ne sub falsarum tractoriarum nomine desertionis suae crimen defendere moliantur, ne subpositis aut conmentis epistulis evadendi habeant facultatem. 2. In desertorum quoque occultatores iuxta promulgatas leges severissime vindicetur. Dat. VI kal. mart. Ravenna Theodosio a. I et Rumorido conss. (403 febr. 24).

${ }^{58}$ Por. Y. Thomas, op. cit., s. 99.

${ }_{59}$ C. 1, 3, 10 (Imperatores Arcadius, Honorius): Si quis in hoc genus sacrilegii proruperit, ut in ecclesias catholicas inruens, sacerdotibus et ministris vel ipso cultu locoque importet iniuriae, quod geritur, a provinciae rectoribus animadvertatur. 1. Atque ita provinciae moderator sacerdotum et catholicae ecclesiae ministrorum, loci quoque ipsius et divini cultus iniuriam capitali in convictos sive confessos reos sententia noverit vindicandum nec expectet, ut episcopus iniuriae propriae ultionem deposcat, cui sanctitas ignoscendi gloriam dereliquit: sitque cunctis laudabile factas atroces sacerdotibus aut ministris iniurias veluti publicum crimen persequi ac de talibus reis ultionem mereri. 2. Quod si multitudo violenta civilis apparitionis exsecutione et adminiculo ordinum possessorumve non potuerit praesentari, quod se armis aut locorum difficultate tueatur, praesides provinciarum etiam militari auxilio per publicas litteras appetito competentem vindicatam tali excessui imponere non morentur. ${ }^{\star}$ ARCAD. ET HONOR. AA. THEODORO PP. ${ }^{*}<$ A 398 D. VI K. MAI. MEDIOLANO HONORIO A. IIII ET EUTYCHIANO CONSS.>

${ }^{60}$ Podobnie traktowano przyznanie się niewolników do winy, którzy dopuścili się przestępstwa przemocy - zob. C.Th. 9, 10, 4 (= C. 9, 12, 8): pr. Servos, qui fecisse violentiam confessionibus testium aut propriis docebuntur, si id inscio domino commiserint, postremo supplicio deditos luere perpetrata censemus. 
Podsumowując, przywołane przekazy źródłowe pozwalają postawić tezę, iż przyznanie się oskarżonego do winy przestało być traktowane w okresie cesarstwa jako wyłączna podstawa skazującego wyroku w rzymskim procesie karnym. Zasada confessus pro iudicato est przestała być w okresie pryncypatu naczelną regułą rządzącą całym rzymskim postępowaniem sądowym. O ile w procesie cywilnym, confessio czyli uznanie roszczenia było traktowane jako akt kończący spór między stronami, który jednocześnie wiązał sędziego ${ }^{61}$. O tyle w procesie karnym, confessio czyli przyznanie się oskarżonego do winy stanowiło zwykły środek dowodowy, który był w zasadzie swobodnie oceniany przez sąd nawet $\mathrm{w}$ okresie poklasycznym ${ }^{62}$.

Jak wykazano, przyznanie się do winy dokonane przez wolnego obywatela rzymskiego w okresie republiki, było traktowane przez sędziów jako „nieomylny głos prawdy i sumienia”, któremu należało w zasadzie bezwarunkowo wierzyćc ${ }^{63}$. Nie dziwi zatem fakt, iż chociażby w procesie przed iudicium populum, pozbawiony inicjatywy dowodowej sąd, był związany przyznaniem się oskarżonego do winy. Takie postępowanie było przede wszystkim jednak wynikiem tego, iż sprawcę czynu postrzegano tylko z punktu widzenia jego skutków, a nie jego motywacji. Dopiero w okresie cesarstwa confessio zostało poddane kontroli, początkowo samego cesarza - który osobiście miał zwyczaj rozstrzygać pewne sprawy karne, a następnie jego urzędników. W pryncypacie, sędzia w którego rolę wcielił się cesarski urzędnik, jako przedstawiciel państwa strzegący jego interesów, został wyposażony w stosowne instrumenty, które miały umożliwić mu dotarcie do prawdy. Tym narzędziem, które miało mu w tym pomóc, stały się tortury. Pojawienie się tortur wydaje się, iż wymusiło zwłaszcza na rzymskiej jurysprudencji zainteresowanie zarówno problematyką zawinienia sprawcy czynu, ale także, a może zwłaszcza, psychologiczną oceną wiarygodności jego wyjaśnień. W efekcie, to właśnie tortury, doprowadziły paradoksalnie do tego, iż przyznanie się do winy przestało być traktowane jako regina probationum ${ }^{64}$. Potwierdzają to konstytucje cesarskie z tego okresu, a zwłaszcza zainteresowanie jurystów kryteriami sądowej oceny dowodów. W tym miejscu warto dodać, iż według zachowanych źródeł, być może już w czasach cesarza Hadriana dopuszczalne stało się torturowanie oskarżonych będących osobami wolnymi, o czym może świadczyć treść zachowanego protokołu śledztwa pochodzącego ze 136

${ }^{61}$ W. Litewski, Studia nad rzymskim postępowaniem kognicyjnym, Kraków 1971, s. 11.

${ }^{62}$ Por. G. Pugliese, Le preuve dans le procès romain de l'Epoque classique, [w:] Recueils de la société Jean Bodin pour l'histoire comparative des instutions. La Preuve, première parie Antiquité, Brüssel 1964, s. 333.

${ }^{63}$ G. Geib, De Confessionis ..., s. 5.

${ }^{64}$ Por. H. Freiherr von Soden, Confessio zwischen Beichte und Geständnis. Eine dogmengeschichtliche Betrachtung über die Entwicklung des Schuldbekenntnisses vom römischen Recht bis zum IV. Lateranum, Düsseldorf 2010, s. 97 
r. n.e. z Egiptu ${ }^{65}$. Torturowanie oskarżonych, zatem być może już wtedy stało się prawnie dozwolone, a nie - jak przyjmuje się według powszechnej opinii dopiero za czasów Sewerów.

Pewien regres w stosunku do okresu klasycznego przyniósł dopiero dominat. Jak już zostało wykazane, w pewnych przypadkach przyznanie się do winy traktowano jako dowód umożliwiający skazanie oskarżonego. Dotyczyło to zwłaszcza tych najcięższych przestępstw, których naruszenie godziło w interes państwa. Nie należy jednak traktować Rzymian jako twórców reguły confessio est regina probationum. Czasy cesarza Justyniana i opracowanie kodyfikacji justyniańskiej opartej w dużej mierze na ustawodawstwie klasycznym, doprowadziły w rzeczywistości do ugruntowania się w rzymskim procesie karnym zasady swobodnej oceny dowodów.

\section{Źródła prawa}

Cicero pro Ligario

I, 2

Livius Ab urbe condita

26, 27

39,17

Sallust Bellum Catlinam

52,36

Seneca Maior Controversiae

8,1

Suetonius De vita Caesarum

Divi Augusti 33

Quintilianus Declamationes

314

Lex duodecim tabularum

3,1

8,12

8,14

Lex Numae

12

Codex lustiniani

$1,3,10$

3,26

$7,59,1$

$7,65,2$

$9,12,8$

Codex Theodosiani

$7,18,11$

$9,10,4$

${ }^{65}$ A. Nogrady, Römisches Strafrecht nach Ulpian. Buch 7 bis De officio proconsulis, Berlin 2006, s. 245. 
Digesta lustiniani

1, 7, 25 pr.

$12,4,15$

$24,1,32,7$

$29,5,6$ pr.

$29,5,17$

$42,1,51$

$42,2,1$

$42,2,3$

$47,2,7,1-3$

$48,3,5$

$48,18,1,17$

$48,18,1,23$

$48,18,1,26-27$

$48,21,2$ pr.

$48,21,3$, pr.-3

$49,14,45,2$

Pauli Sententiae

5, 26, 2

\section{Bibliografia}

Amielańczyk K., Crimina legitima w rzymskim prawie publicznym, Lublin 2013.

Amielańczyk K., Głos cesarza Hadriana w sprawie s.c. Silanianum, [w:] Zeszyty Prawnicze UKSW 6.1 (2006), s. 9-25.

Amielańczyk K., Lex Cornelia de sicariis et venefisis. Ustawa Korneliusza Sulli przeciwko nożownikom i trucicielom 81 r.p.n.e., Lublin 2011.

Amielańczyk K., Quaestio per tormenta. O wartości dowodowej zeznań uzyskanych za pomoca tortur w rzymskim procesie karnym okresu pryncypatu, [w:] O prawie i jego dziejach. Księgi dwie. Studia ofiarowane Profesorowi Adamowi Lityńskiemu w czterdziestopięciolecie pracy naukowej i siedemdziesięciolecie urodzin, Ks. I, Białystok-Katowice 2010, s. 51-62.

Amielańczyk K., Rzymskie prawo karne w reskryptach cesarza Hadriana, Lublin 2006.

Amielańczyk K., Znaczenie "opinii publicznej" dla przebiegu rzymskiego procesu karnego. Uwagi na marginesie mów obrończych Cycerona w sprawach o zabójstwa, [w:] Społeczeństwo a władza. Ustrój, prawo, idee, pod. red. J. Przygodzkiego i M.J. Ptaka, Kolonia Limited 2010, s. 145-160.

Chmiel A., Ochrona bezpieczeństwa właścicieli niewolników w świetle S.C. Silanianum, [w:] Ochrona bezpieczeństwa i porządku publicznego w prawie rzymskim, pod. red. K. Amielańczyka, A. Dębińskiego, D. Słapka, Lublin 2010, s. 53-64.

Chmiel A., Proces katylinarczyków jako przykład rzymskiego "procesu politycznego", [w:] Prawo karne i polityka w państwie rzymskim, red. K. Amielańczyk, A. Dębiński, D. Słapek, Lublin 2015, s. 47-62.

Chmiel A., Przykład zastosowania s.c. Silanianum, czyli o tym, dlaczego rzymska iustitia stawała się niekiedy okrutna, [w:] Przemoc w świecie starożytnym. Źródła, struktury, interpretacje, red. D. Słapek, I. Łuć, Lublin 2017, s. 299-310.

Chmiel A., Ustrój rzymskich organów jurysdykcyjnych w sprawach karnych, Studia Prawnoustrojowe 12 (2010), s. 49-55.

Chmiel A., Zasada crimen extinguitur mortalitate a samobójstwo oskarżonego w rzymskim procesie karnym, [w:] Justynian i prawo rzymskie. Refleksje w 1450. Rocznicę śmierci cesarza, pod red. K. Szczygielskiego, Białystok 2015, s. 97-112. 
David J-M., La faute de l'abandon. Théories et pratiques judiciaires à Rome à la fin de la République, [w:] L'aveu. Antiquité et Moyen Âge. Actes de la table ronde de Rome (28-30 mars 1984), Roma 1986, s. 69-87.

Dębiński A., Poena cullei w rzymskim prawie karnym, Prawo Kanoniczne 37, nr 3-4 (1994), s. 133-146.

Digesta lustiniani. Digesta Justyniańskie. Tekst i przekład, VII, 2, ks. 48-50, pod red. T. Palmirskiego, Kraków 2017.

Dyjakowska M.H., Procesy chrześcijan w świetle korespondencji Pliniusza Młodszego, [w:] Cuius regio, eius religio, Lublin 2006, s. 25-40.

Ermann J., Strafprozeß, öffentliches Interesse und private Strafverfolgung, Köln-Weimar-Wien 2000. Frantzen M., Mors voluntaria in reatu: Die Selbsttötung im klassischen römischen Recht, Gottingen 2012. Freiherr von Soden H., Confessio zwischen Beichte und Geständnis. Eine dogmengeschichtliche Betrachtung über die Entwicklung des Schuldbekenntnisses vom römischen Recht bis zum IV. Lateranum, Düsseldorf 2010.

Gagliardi L., 'lure caesus esto', Labeo 45 (1999), s. 421-439.

Gajus Swetoniusz Trankwillus, Żywoty Cezarów, przeł. J. Niemirska-Pliszczyńska, wyd. 5, Wrocław-Warszawa-Kraków-Gdańsk 1972.

Geib G., De Confessionis Effectu in processu criminali romanorum, Turici 1837.

Gioffredi C., L'elemento intenzionale nel diritto penale romano, [w:] Studi in onore di G. Grosso III, Torino 1970, s. 35-53.

Girdwoyń K., Ogólna charakterystyka procesu karnego w Anglii i Walii, [w:] System prawa karnego procesowego, t. Il. Proces karny. Rozwiq̨zania modelowe w ujęciu prawnoporównawczym, red. P. Kruszyński, Warszawa 2014, s. 686-692.

Jońca M., < In > iis qui ad me tamquam christiani deferebantur, hunc sum secutus modum. Środki dowodowe zastosowane w procesie chrześcijan pontyjskich w relacji Pliniusza Młodszego (Ep. 10, 96), Zeszyty Prawnicze UKSW 5.2 (2005), s. 99-115.

Jońca M., Exilium jako przejaw humanitas w rzymskim prawie karnym okresu republiki, [w:] Humanitas grecka i rzymska, pod red. R. Popowskiego, Lublin 2005, s. 191-202.

Jońca M., Exilium voluntarium, czyli luksus dla wybranych, CPH, t. LX, z. 2 (2008) s. 363-369.

Jońca M., Głośne rzymskie procesy karne, Wrocław 2009.

Jońca M., Parricidium w prawie rzymskim, Lublin 2008.

Jońca M., The Scope of exilium voluntarium in the Roman Republic, [w:] La repressione criminale nella Roma repubblicana fra norma e persuasione, (a cura di B. Santalucia), Pavia 2009, s. 77-91.

Kelly G.P., A History of Exile in the Roman Republic, Cambridge 2006.

Kipp T., s.v. confessio, «RE» 4.1 (1900), szp. 870-871.

Kmiecik R. (red.), Prawo dowodowe. Zarys wykładu, Warszawa 2008.

Kunkel K., Prinzipien des römischen Strafverfahrens, [w:] Kleine Schriften. Zum römischen Strafverfahren und zur römischen Verfassungsgeschichte, Weimar 1974, s. 11-31.

Kunkel W., Quaestio, [w:] Kleine Schriften. Zum römischen Strafverfahren und zur römischen Verfassungsgeschichte, Weimar 1974, s. 33-110.

Litewski W., Confessio in iure e sententia, Labeo 22/2 (1976), s. 252-267.

Litewski W., Rzymski proces karny, Kraków 2003.

Litewski W., Studia nad rzymskim postępowaniem kognicyjnym, Kraków 1971.

Loska E., Obowiq̨zek niewolników obrony swojego właściciela, Zeszyty Prawnicze UKSW 4.1 (2004), s. $45-56$

Loska E., Zagadnienie obrony koniecznej w rzymskim prawie karnym, Warszawa 2011.

Manni A., Mors omnia solvit. La morte del reus nel processo criminale romano, Napoli 2013.

Marek A., Prawo karne, Warszawa 2006.

Marotta V., Morte rei iudicium solvitur, INDEX 43 (2015), s. 456-464.

Mommsen T, Römisches Strafrecht, Leipzig 1899 (nachdruck Graz 1955).

Mowy Marka Tulliusza Cycerona, przeł. przez E. Rykaczewskiego, t. III, Paryż 1870. 
Nogrady A., Römisches Strafrecht nach Ulpian. Buch 7 bis De officio proconsulis, Berlin 2006.

Nörr D., Causa mortis, München 1986.

Pugliese G., Le preuve dans le procès romain de l'Epoque classique, [w:] Recueils de la société Jean Bodin pour I'histoire comparative des instutions. La Preuve, première parie Antiquité, Brüssel 1964, s. 277-348.

Rein W., Das Criminalrecht der Römer von Romulus bis auf Justynian, Leipzig 1844.

Rilinger R., Honestiores - Humiliores: zu einer sozialen Dichotomie im Strafrecht der römischen Kaiserzeit, München 1988.

Sanders A., Young R., Burton M., Criminal Justice, wyd. IV, Oxford University Press, New York 2010.

Santalucia B., Diritto e processo penale nell'antica Roma, Milano 1989.

Santalucia B., Il diritto penale e la codificazione decemvirale, [w:] Lineamenti di storia del diritto romano, red. M. Talamanca, Milano 1989, s. 126-133.

Santalucia B., Osservazioni sui duuviri perduellionis e sul procedimento duumvirale, [w:] Du ch囚timent dans la cite. Supplices corporals et peine de mort dans le monde antique. Table ronde organisée par l'École française de Rome avec le concours du Centre national de la recherché scientifique (Rome 9-11 novembre 1982), Rome 1984, s. 439-452.

Scapini N., Diritto e procedura penale nell'esperienza giuridica romana, Parma 1992.

Scapini N., La confessione nel diritto romano. I: Diritto classico, Torino 1973.

Scapini N., La confessione nel diritto romano. Il: Diritto giustinianeo, Milano 1983.

Sitek B., ", Quaestionem" intellegere debemus tormenta et corporis dolorem ad eruendam veritatem, [w:] Crimina et mores. Prawo karne i obyczaje w starożytnym Rzymie, pod red. M. Kuryłowicza, Lublin 2001, s. 161-168.

Thomas Y., Confessus pro iudicato. L'aveu civil et l'aveu pénal à Rome, [w:] L'aveu. Antiquité et Moyen Âge. Actes de la table ronde de Rome (28-30 mars 1984), Roma 1986, s. 89-117.

Tytus Liwiusz, Dzieje Rzymu od założenia miasta, ks. XXXV-XL, przeł. i oprac. M. Brożek, Wrocław-Warszawa-Kraków-Gdańsk-Łódź 1981.

Wacke A., Audiatur et altera pars zum rechtlichen gehoer im roemischen zivil- und strafprozess, [w:] Ars boni et aequi. Festsschrift fuer W. Waldstein zum 65., Stuttgart 1993, s. 369-399.

Wacke A., Der Selbsmord im römischen Recht und der Rechtsentwicklung, ZSS 97 (1980), s. 26-77.

Zumpt A.W., Römisches Criminalrecht, t. I.1, Berlin 1865.

Przyznanie się oskarżonego do winy w rzymskim procesie karnym

\section{Streszczenie}

Przyznanie się oskarżonego do winy przez cały okres republiki aż do II wieku n.e. było traktowane jako wystraczająca podstawa do wydania skazującego wyroku w rzymskim procesie karnym. Takie postępowanie było przede wszystkim wynikiem tego, iż czyn sprawcy postrzegano tylko z punktu widzenia jego skutków, a nie motywacji oskarżonego. Dopiero w okresie cesarstwa confessio zostało poddane kontroli początkowo samego cesarza, a następnie jego urzędników. W czasach pryncypatu sędzia, w którego rolę wcielał się cesarski urzędnik, został wyposażony w stosowne narzędzie, które miało umożliwić mu dotarcie do prawdy. Tym ostatnim stały się tormenta. Wydaje się, iż to właśnie pojawienie się tortur wymusiło zwłaszcza na rzymskiej jurysprudencji zainteresowanie, zarówno problematyką zawinienia sprawcy czynu, ale także, psychologiczną oceną wiarygodności jego wyjaśnień. W efekcie, to tormenta doprowadziły do tego, iż przyznanie się do winy przestało być traktowane w rzymskim procesie karnym jako regina probationum.

Słowa kluczowe: rzymski proces karny, oskarżony, wyjaśnienia, przyznanie się do winy, tortury. 


\section{Defendant's Confession in the Roman Criminal Procedure}

\section{Summary}

During the whole period of the Roman Republic until the second century AD, defendant's confession was regarded as a sufficient basis for conviction in the Roman criminal procedure. This approach resulted mostly from the fact that the perpetrator's act was viewed only from the perspective of its effects and not the defendant's motives. Only during the Roman Empire period confessio came under the supervision of first the Caesar himself and then his officials. During the Principate period, a judge, whose role was fulfilled by a Caesar's official, was granted certain tools which were supposed to help him find out the truth. These tools were tormenta. It seems that the introduction of torture forced especially the Roman jurisprudence to become interested in the problem of the perpetrator's guilt and also in psychological evaluation of credibility of the culprit's testimony. Consequently, it was due to tormenta that confession ceased to be regarded as regina probationum in the Roman criminal procedure.

Keywords: Roman criminal procedure, defendant, testimony, confession, tortures 